\title{
Uji Efektivitas Ekstrak Etanol Daun Upo-upo (Phyllodium pulchellum (L.) Desv.) sebagai Antibakteri terhadap Pertumbuhan Streptococcus viridans dan Streptococcus pyogenes
}

\author{
Dewi Isnaeni, Andi Ulfa Magefirah Rasyid, dan Rahmawati \\ Fakultas Farmasi, Universitas Indonesia Timur, Makassar, Indonesia \\ Correspondence: Dewi Isnaeni \\ Email: dewiisnaeni73@gmai.com
}

Submitted : 06-11-2020, Revised : 25-03-2021, Accepted : 16-06-2021

\begin{abstract}
ABSTRAK : Telah dilakukan penelitian untuk menguji efektivitas ekstrak etanol daun Upo-upo (Phyllodium pulchellum (L.) Desv.) terhadap pertumbuhan Streptococcus viridans dan Streptococcus pyogenes. Penelitian ini bertujuan untuk menentukan konsentrasi ekstrak yang paling efektif. Penelitian ini menggunakan metode ekstraksi maserasi terhadap bahan uji dan uji mikrobiologis menggunakan metode Disc diffusion menurut Kirby \& Bauer dengan konsentrasi ekstrak 1; 1,5; 2; dan 2,5\%, dengan kontrol positif cefixime dan kontrol negatif CMC Na 1\%. Hasil pengujian menunjukkan bahwa ekstrak etanol daun Upo-upo dapat menghambat pertumbuhan $S$. viridans pada konsentrasi ekstrak $1 ; 1,5 ; 2 ;$ dan 2,5\%, masing-masing dengan diameter hambatan 9,01; 9,58; 10,24; dan 12,27 mm, sedangkan zona hambatan untuk kontrol positif 22,07 mm dan kontrol negatif tanpa zona hambatan. Zona hambatan terhadap $S$. pyogenes pada konsentrasi ekstrak 1; 1,5; 2; dan 2,5\% masing-masing adalah 9,51; 9,91; 10,93; dan 13,59 $\mathrm{mm}$, dimana zona hambatan kontrol positif $25,77 \mathrm{~mm}$ dan kontrol negatif tanpa zona hambatan. Dapat disimpulkan bahwa ekstrak etanol daun Upo-upo pada semua tingkat konsentrasi mempunyai efektivitas antibakteri terhadap S. viridans dan S. pyogenes. Efektivitas antibakteri ekstrak etanol daun Upo-upo terhadap pertumbuhan $S$. viridans dan $S$. pyogenes menunjukkan bahwa semakin tinggi konsentrasi ekstrak, maka semakin besar pula zona hambat yang dihasilkan. Konsentrasi yang paling efektif adalah 2,5\%.
\end{abstract}

Kata kunci: Daun Upo-upo; Phyllodium pulchellum (L.) Desv.; Streptococcus viridans; Streptococcus pyogenes

\begin{abstract}
This research was carried out to investigate the activity of ethanol extract of Upo-upo (Phyllodium pulchellum (L.) Desv.) leaves against two types of bacteria, i.e.: Streptococcus viridans and Streptococcus pyogenes. This study aimed to determine the most effective concentration of the extract. The extraction method used was maceration and the microbiological tests used was the disc diffusion method according to Kirby \& Bauer with the concentrations of extract were $1 ; 1.5 ; 2$; and $2.5 \%$, with cefixime as a positive control and $1 \%$ CMC Na as a negative control. The results showed that the ethanol extract of Upo-upo leaves could inhibit the growth of $S$. viridans at the concentrations of $1 ; 1.5 ; 2$; and 2.5\%, with the inhibition zones of $9.01 ; 9,58 ; 10,24 ;$ and $12.27 \mathrm{~mm}$, respectively; while the inhibition zone for positive control was $22.07 \mathrm{~mm}$ and negative control without the inhibition zone. The inhibition zones of the extract at the concentrations of $1 ; 1.5 ; 2 ;$ and $2.5 \%$ against S. pyogenes were 9.51; 9.91; 10.93; and $13.59 \mathrm{~mm}$, respectively; where the inhibition zone for positive control was 25.77 $\mathrm{mm}$ and negative control without the inhibition zone. It can be concluded that the ethanol extract of Upo-upo leaves at all concentration levels had antibacterial activity against $S$. viridans and S. pyogenes. Moreover, the higher concentration of the extract, the greater the inhibition zone. The most effective concentration was $2.5 \%$.
\end{abstract}

Keywords: Upo-upo Leaves, Phyllodium pulchellum (L.) Desv., Streptococcus viridans, Streptococcus pyogenes 


\section{Pendahuluan}

Infeksi saluran pernapasan akut (ISPA) adalah infeksi yang paling banyak terjadi pada manusia di segala umur. Anak-anak dan bayi yang paling rentan terkena infeksi [1]. ISPA menduduki urutan pertama dalam jumlah pasien rawat jalan. Kejadian ISPA di Indonesia pada tahun 2013 menunjukkan prevalensi sebesar 4,5\%. ISPA tertinggi pada kelompok umur 1-4 tahun $(25,8 \%)$ [2]. Hal ini menunjukkan jumlah gangguan kesehatan akibat ISPA masih tinggi. Salah satu jenis ISPA bagian atas yaitu tonsilitis [3]. Angka kejadian penyakit tonsilitis di Indonesia sekitar 23\% [4]. Tonsilitis merupakan awal keadaan infeksi dari infeksi saluran pernapasan akut [5]. Tonsilitis akut paling banyak disebabkan oleh Streptococcus $\beta$ hemoliticus. Sekitar $30-40 \%$ tonsilitis akut disebabkan oleh Streptococcus $\beta$ hemoliticus group A [6]. group A dan secara kolektif mengacu pada Streptococcus pyogenes dan kelompok Streptococcus viridans merupakan patogen yang sangat penting pada manusia. Anggota-anggota group ini merupakan penyebab utama infeksi saluran napas manusia seperti tonsilitis [3,7]. Brook menyatakan dalam mendiagnosis tonsilitis keterlibatan Streptococcus $\beta$ hemoliticus group A harus tetap dipertimbangkan disamping bakteri lain yang juga dapat ditemukan pada pemeriksaan bakteriologi [6].

Tonsilitis merupakan peradangan pada tonsil palatina atau dikenal juga sebagai radang amandel. Tonsil menstimulasi sistem imun untuk memproduksi antibodi. Lokasi tonsil sangat memungkinkan terpapar benda asing dan patogen, selanjutnya membawanya ke sel limfoid. Jika tonsil tidak mampu melindungi tubuh, maka akan timbul inflamasi dan akhirnya terjadi infeksi. Gambaran klinis pada peradangan tonsil yaitu demam, terdapat pembesaran tonsil/eksudat pada tonsil, pembesaran kelenjar servikal anterior dan tidak ada batuk $[3,8]$.

Streptococcus pyogenes dapat mengekspresikan beberapa komponen pada matriks ekstraseluler yang melekat pada fibronektin (Fn), protein, matriks, atau kolagen. Fibronektin (Fn) inilah yang menjadi salah satu faktor virulensi dari streptokokus karena memegang pengaruh besar terhadap pelekatan $S$. pyogenes pada sel epitel manusia. Protein $M$ juga berperan dalam pelekatan S. pyogenes pada sel tubuh manusia [9]. Streptococcus pyogenes termasuk salah satu bakteri yang resisten dengan beberapa jenis antibiotik sehingga menyulitkan pengobatannya $[9,10]$. Penelitian yang dilakukan oleh Isnaeni dkk. (2012) di Puskesmas Kassi-Kassi Makassar menunjukkan bahwa pada swab tonsil diperoleh 15 sampel bakteri Streptococcus $\beta$ hemoliticus penyebab tonsilitis dari 50 sampel pasien anakanak dan dewasa [11].

Daun Upo-upo (Phyllodium pulchellum (L.) Desv.) merupakan salah satu tanaman obat yang banyak tumbuh dan digunakan sebagai obat amandel atau tonsil di Dusun Bangkengtabbing Kecamatan Garing, Kabupaten Gowa, Provinsi Sulawesi Selatan. Tanaman ini memiliki potensi sebagai antiinflamasi, antibakteri, antivirus, dan antioksidan. Ekstrak metanol daun Upo-upo dapat digunakan sebagai antidiare [12]. Pada pengobatan Cina, P. pulchellum digunakan untuk demam rematik, bayi kejang, sakit gigi, dan menghentikan pendarahan [13]. Berdasarkan uraian di atas, perlu dilakukan penelitian uji efektivitas ekstrak etanol daun Upo-upo sebagai antibakteri terhadap pertumbuhan $S$. viridans dan $S$. pyogenes.

\section{Metode}

\subsection{Alat dan bahan}

Alat-alat yang digunakan pada penelitian ini meliputi bejana maserasi, rotavapor, autoklaf (GEA YX-18 LDJ), oven (Memmert), inkubator (Incucell), lemari es, timbangan kasar, timbangan analitik (ADAM), mikroskop binokuler, lampu spritus (kaca), kawat ose bulat (gagang kaca), Laminar Air Flow (N-Biotek Leading), jangka sorong (Vernier caliper), spoit, mikropipet (Eco pipette by APP $50 \mu \mathrm{L}$ ), waterbath, dan alat-alat gelas laboratorium. 
Bahan-bahan yang digunakan antara lain: daun Upo-upo (Phyllodium pulchellum (L.) Desv.), aquadest, aquadest steril, etanol $70 \%$, etanol 96\%, medium Nutrient Agar (Oxoid), medium Mueller Hinton Agar (Oxoid), biakan murni Streptococcus viridans, biakan murni Streptococcus pyogenes, antibiotik cexifime, CMC Na 1\%, cotton swab steril, paper disc, kapas steril, iodine, kristal violet, safranin, minyak imersi, $\mathrm{NaCl} 0,9 \%, \mathrm{H}_{2} \mathrm{SO}_{4}$ pekat, $\mathrm{FeCl}_{3}$, serbuk magnesium, $\mathrm{HCl}$ pekat, dan $\mathrm{HCl} 2 \mathrm{~N}$.

\subsection{Prosedur kerja}

\subsubsection{Pengolahan bahan uji}

Daun Upo-upo diperoleh dari Dusun Bangkengtabbing, Desa Garing, Kecamatan Tompo Bulu, Kabupaten Gowa, Provinsi Sulawesi Selatan dan telah dideterminasi oleh Lembaga Ilmu Pengetahuan Indonesia (LIPI), Pusat Penelitian Biologi Cibinong dengan Nomor surat determinasi 824/IPH.1.01/If.07/VIII/2020. Bahan uji yang telah dikumpulkan disortasi basah dengan dicuci di air yang mengalir, kemudian dipotong kecil-kecil dan dikeringkan dengan cara diangin-anginkan tanpa matahari langsung.

\subsubsection{Penyiapan ekstrak}

Simplisia ditimbang sebanyak 700 gram kemudian dimasukkan ke dalam bejana maserasi, selanjutnya ditambahkan etanol 96\% dengan perbandingan 1 bagian simplisia kering : 10 bagian pelarut. Maserasi dilakukan selama 5x24 jam sambil sesekali diaduk menggunakan batang pengaduk. Filtrat disaring, residunya dimaserasi kembali (remaserasi) dengan pelarut yang sama. Ekstrak hasil maserasi kemudian diuapkan dengan menggunakan rotary evaporator untuk mendapatkan ekstrak pekat daun Upo-upo.

\subsubsection{Skrining fitokimia}

\subsubsection{Identifikasi alkaloid}

Ekstrak sampel ditambahkan $\mathrm{HCl} 2 \mathrm{~N}$ dan ditambahkan 2-3 tetes pereaksi Mayer. Jika terbentuk endapan putih kekuning-kuningan pada sampel menunjukkan adanya alkaloid.
Diambil $1 \mathrm{~mL}$ ekstrak, dimasukkan ke dalam plat tetes, ditambahkan beberapa tetes pereaksi Dragendorff, jika terjadi perubahan warna jingga, maka positif mengandung alkaloid [14].

\subsubsection{Identifikasi flavonoid}

Ekstrak sampel sebanyak $2 \mathrm{~mL}$ dimasukkan ke dalam tabung reaksi ke-1, kemudian ditambahkan beberapa mg serbuk Mg dan $1 \mathrm{~mL} \mathrm{HCl}$ pekat. Perubahan warna larutan menjadi warna merah jingga sampai merah ungu menunjukkan adanya flavonoid. Untuk tabung reaksi ke-2 dimasukkan sampel sebanyak $3 \mathrm{~mL}$, kemudian ditambahkan beberapa tetes $\mathrm{NaOH} 20 \%$, maka akan terbentuk warna kuning jika mengandung flavonoid [14].

\subsubsection{Identifikasi saponin}

Ekstrak sampel sebanyak $2 \mathrm{~mL}$ dimasukkan ke dalam tabung reaksi, lalu ditambahkan $10 \mathrm{~mL}$ air panas, setelah itu didinginkan dan dikocok secara kuat selama 30 detik sehingga terbentuk buih dan tidak hilang selama 10 menit setinggi 1-10 cm yang menunjukkan adanya saponin [14].

\subsubsection{Identifikasi tanin}

Ekstrak sampel dimasukkan ke dalam tabung reaksi, dilarutkan dalam $2 \mathrm{~mL}$ air dan ditambahkan 3 tetes $\mathrm{FeCl}_{3}$ 1\%. Timbulnya warna biru kehitaman dan hijau kehitaman menunjukkan adanya senyawa tanin [14].

\subsubsection{Identifikasi terpenoid}

Ekstrak sampel dilarutkan dengan pereaksi Liebermann Burchard (asam asetat anhidrat dan asam sulfat pekat). Sampel yang mengandung senyawa golongan terpenoid akan berubah warna membentuk cincin coklat atau violet [14].

\subsubsection{Pembuatan suspensi CMC Na $1 \%$}

Ditimbang $1 \mathrm{~g}$ CMC Na, kemudian dimasukkan sedikit demi sedikit ke dalam $50 \mathrm{~mL}$ air suling yang telah dipanaskan, sambil diaduk dengan menggunakan batang pengaduk hingga terbentuk larutan koloidal yang homogen selanjutnya dicukupkan volumenya hingga $100 \mathrm{~mL}$. 


\subsubsection{Pembuatan suspensi ekstrak}

Ekstrak etanol yang diperoleh dari hasil maserasi, dibuat suspensi dengan konsentrasi 1 ; 1,$5 ; 2$; dan $2,5 \%$. Untuk membuat suspensi ekstrak 1\%, ditimbang $1 \mathrm{~g}$ ekstrak etanol daun Upo-upo, lalu disuspensikan dalam CMC Na 1\% hingga $100 \mathrm{~mL}$. Dilakukan hal yang sama seperti di atas dengan cara ditimbang ekstrak masingmasing 1,5; 2; dan 2,5 g.

\subsubsection{Penyiapan bakteri uji}

Bakteri yang digunakan adalah Streptococcus viridans dan Streptococcus pyogenes dari stok murni. Masing-masing diambil 1 ose, lalu diinokulasi pada masing-masing media Nutrient Agar miring, diinkubasi selama 1x24 jam pada suhu $37^{\circ} \mathrm{C}$. Bakteri uji yang telah diinokulasi diambil dengan kawat ose steril lalu disuspensikan ke dalam tabung yang berisi 2 mL larutan $\mathrm{NaCl}$ 0,9\% hingga diperoleh kekeruhan larutan Mc Farland. Perlakuan yang sama dilakukan pada setiap jenis bakteri uji [15].

\subsubsection{Pembuatan larutan kontrol positif}

Ditimbang 103 mg serbuk kapsul Cefixime yang setara dengan 50 mg Cefixime, dimasukkan ke dalam labu ukur $100 \mathrm{~mL}$, lalu dicukupkan volumenya dengan suspensi CMC Na hingga tanda batas sebagai larutan stok (500 bpj). Dipipet 3 mL dari larutan stok ke dalam labu ukur $10 \mathrm{~mL}$, dicukupkan volumenya dengan suspensi CMC Na hingga tanda batas sebagai pengenceran I (150 bpj). Dipipet $2 \mathrm{~mL}$ dari pengenceran tersebut, lalu dimasukkan ke dalam labu ukur $10 \mathrm{~mL}$, dicukupkan volumenya hingga tanda batas (30 bpj).

\subsubsection{Pengujian efektivitas ekstrak etanol daun Upo-upo}

Medium Mueller Hinton Agar sebanyak 20 mL dituang secara aseptik ke dalam cawan petri steril dan dibiarkan memadat, lalu diswab merata dengan suspensi bakteri S. viridans dan S. pyogenes pada masing-masing di atas media MHA tersebut dengan menggunakan cotton swab steril. Diletakkan paper disc di atas media MHA yang sebe- lumnya telah direndam dalam larutan bahan uji ekstrak etanol daun Upo-upo konsentrasi 1; 1,5; 2; dan 2,5\% dan kontrol negatif menggunakan CMC Na 1\% dan kontrol positif menggunakan cefixime 30 bpj selama 15 menit dengan jarak satu sama lainnya kurang lebih sama $[16,17]$. Pengamatan dilakukan setelah 1x24 jam masa inkubasi pada suhu $37^{\circ} \mathrm{C}$. Zona bening merupakan petunjuk kepekaan mikroba terhadap bahan antimikroba yang digunakan sebagai bahan uji yang dinyatakan dengan lebar diameter zona hambat. Perlakuan dilakukan sebanyak tiga kali dan diambil rata-ratanya [18].

\subsection{Analisis data}

Data hasil penelitian yaitu diameter zona hambat dianalisis secara statistik menggunakan One Way Anova dengan bantuan program SPSS.

\section{Hasil dan pembahasan}

Skrining fitokimia (Tabel 1) yang telah dilakukan pada ekstrak etanol daun Upo-upo menunjukkan adanya kandungan beberapa senyawa metabolit sekunder diantaranya alkaloid, flavonoid, tanin, dan terpenoid. Hal ini sesuai dengan penelitian sebelumnya yang dilakukan oleh Velmurugan dan Anand (2016), yang menunjukkan bahwa daun Phyllodium pulchellum mengandung alkaloid, flavonoid, steroid, terpenoid, tanin, saponin, dan fenol [20].

Pengujian efektivitas ekstrak etanol daun Upoupo terhadap pertumbuhan Streptococcus viridans dengan masa inkubasi $1 \times 24$ jam pada suhu $37^{\circ} \mathrm{C}$ diperoleh diameter zona hambatan rata-rata untuk konsentrasi $1 ; 1,5 ; 2$; dan 2,5\%v masingmasing sebesar 9,01; 9,58; 10,24; dan 12,27 mm. Kontrol positif (cefixime $30 \mathrm{bpj}$ ) menunjukkan diameter hambatan rata-rata 22,07 $\mathrm{mm}$, sedangkan kontrol negatif (CMC Na 1\%) tidak menyebabkan adanya zona hambatan. Daya hambat pada empat konsentrasi tersebut tergolong kategori sedang sampai kuat [21]. Data hasil pengujian diameter zona hambat dapat dilihat pada Tabel 2 dan Gambar 1.

Analisis data dengan menggunakan One Way 
Tabel 1. Hasil skrining fitokimia ekstrak etanol daun Upo-upo

\begin{tabular}{|c|c|c|c|c|}
\hline Golongan & Reagen & Hasil reaksi [19] & Hasil penelitian & Keterangan \\
\hline \multirow[t]{2}{*}{ Alkaloid } & Mayer & $\begin{array}{l}\text { Endapan putih atau keruh } \\
\text { Endapan oranye }\end{array}$ & $\begin{array}{l}\text { Endapan putih keruh } \\
\text { Kuning }\end{array}$ & + \\
\hline & Dragendorff & & & - \\
\hline Flavonoid & Mg HCl pekat & Kuning & Kuning & + \\
\hline Saponin & Aquadest, $\mathrm{HCl} 2 \mathrm{~N}$ & Terbentuk buih/busa & $\begin{array}{l}\text { Tidak terbentuk buih/ } \\
\text { busa }\end{array}$ & - \\
\hline Tanin & Aquadest, $\mathrm{FeCl}_{3}$ & Hijau kehitaman & Hijau kehitaman & + \\
\hline Terpenoid & $\begin{array}{l}\mathrm{H}_{2} \mathrm{SO}_{4} \text { pekat, Asam asetat } \\
\text { anhidtrat }\end{array}$ & $\begin{array}{l}\text { Warna merah jingga atau } \\
\text { ungu }\end{array}$ & Ungu kebiru- biruan & + \\
\hline
\end{tabular}

Tabel 2. Diameter zona hambat ekstrak etanol daun Upo-upo terhadap S. viridans

\begin{tabular}{lllllll}
\hline Replikasi & \multicolumn{5}{l}{ Diameter zona hambat (mm)* } \\
\hline & Kontrol (-) & \multicolumn{2}{l}{ Konsentrasi ekstrak (\%) } & & Kontrol (+) \\
& & $\mathbf{1}$ & $\mathbf{1 , 5}$ & $\mathbf{2}$ & $\mathbf{2 , 5}$ & \\
\hline 1 & 6 & 9,00 & 9,58 & 9,58 & 11,60 & 22,60 \\
2 & 6 & 9,00 & 9,58 & 10,54 & 12,61 & 22,60 \\
3 & 6 & 9,02 & 9,58 & 10,60 & 12,61 & 21,00 \\
\hline Rerata \pm SD & $6 \pm 0$ & $9,01 \pm 0,01$ & $9,58 \pm 0$ & $10,24 \pm 0,57$ & $12,27 \pm 0,58$ & $22,07 \pm 0,92$ \\
\hline
\end{tabular}

*Kontrol (-): CMC Na 1\%, kontrol (+): cefixime 30 bpj

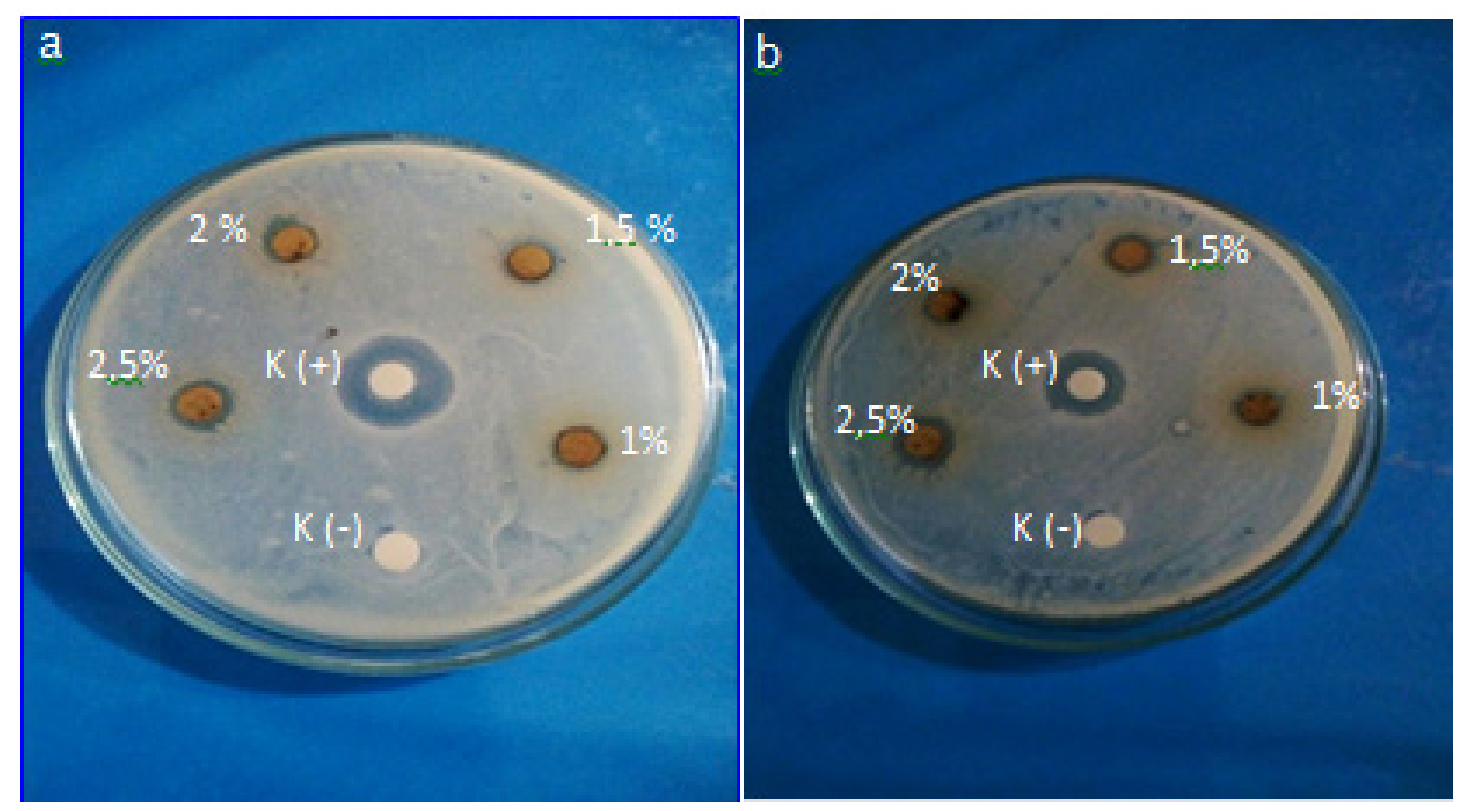

Gambar 1. Diameter zona hambat ekstrak etanol daun Upo-upo terhadap pertumbuhan S. viridans (a) dan S. pyogenes (b)

K (+): cefixime 30 bpj; K (-): CMC Na 1\%; 1\%, 1,5\%, 2\%, 2,5\% masing-masing adalah ekstrak etanol daun Upo-upo konsentrasi 1; 1,5; 2; dan 2,5\%.

Anova untuk mengetahui apakah terdapat per- $\quad$ bedaan bermakna zona hambat terhadap S. viri- 
dans antara variasi konsentrasi ekstrak etanol daun Upo-upo, diperoleh nilai Sig. $0.000(<0,05)$. Hal ini menunjukkan bahwa terdapat perbedaan yang bermakna antara variasi konsentrasi terhadap zona hambat yang dihasilkan. Semakin tinggi konsentrasi ekstrak etanol daun Upo-upo, semakin besar pula zona hambat yang dihasilkan terhadap S. viridans.

Zona hambat yang terbentuk pada pengujian efektifvitas ekstrak daun Upo-upo terhadap pertumbuhan $S$. pyogenes dengan masa inkubasi 1 x24 jam pada suhu $37^{\circ} \mathrm{C}$ diperoleh diameter hambatan rata-rata untuk konsentrasi 1; 1,5; 2; dan 2,5\% masing-masing sebesar 9,51; 9,91; 10,93; dan 13,59 mm. Kontrol positif (cefixime $30 \mathrm{bpj}$ ) memberikan diameter hambatan ratarata 25,77 mm, sedangkan kontrol negatif (CMC Na 1\%) tidak memberikan zona hambatan. Daya hambat pada empat konsentrasi tersebut dapat dikatakan dalam kategori sedang sampai kuat [21]. Data hasil pengujian diameter zona hambat dapat dilihat pada Tabel 3 dan Gambar 1.
Analisis data dengan menggunakan One Way Anova untuk mengetahui apakah terdapat perbedaan bermakna zona hambat terhadap $S$. pyogenes antara variasi konsentrasi ekstrak etanol daun Upo-upo, juga didapatkan nilai Sig. 0.000 $(<0,05)$. Hal ini menunjukkan bahwa terdapat perbedaan yang bermakna antara variasi konsentrasi terhadap zona hambat yang dihasilkan. Semakin tinggi konsentrasi ekstrak etanol daun Upo-upo, semakin besar pula zona hambat yang dihasilkan terhadap S. pyogenes.

Penggolongan kekuatan daya antimikroba menurut Davis and Stout (1971), yaitu jika diameter zona bening < $5 \mathrm{~mm}$ dikategorikan sedang, 10-20 mm dikategorikan kuat, dan $>20 \mathrm{~mm}$ dikategorikan sangat kuat [21]. Hasil uji di atas menunjukkan bahwa ekstrak etanol daun Upoupo (mempunyai daya hambat antibakteri kategori sedang sampai kuat terhadap S. viridans dan S. pyogenes karena diameter zona hambat yang terbentuk masing-masing antara 9,01-12,27 mm dan 9,51-13,59 mm.

Tabel 3. Diameter zona hambat ekstrak etanol daun Upo-upo terhadap S. pyogenes

\begin{tabular}{lllllll}
\hline Replikasi & \multicolumn{6}{l}{ Diameter zona hambat (mm)* } \\
\hline & Kontrol (-) & \multicolumn{2}{l}{ Konsentrasi ekstrak (\%) } & & Kontrol (+) \\
& & $\mathbf{1}$ & $\mathbf{1 , 5}$ & $\mathbf{2}$ & $\mathbf{2 , 5}$ & \\
\hline 1 & 6 & 9,00 & 9,60 & 10,60 & 12,65 & 25,5 \\
2 & 6 & 9,00 & 9,60 & 10,60 & 13,59 & 25,5 \\
3 & 6 & 10,54 & 10,54 & 11,60 & 14,53 & 26,3 \\
\hline Rerata \pm SD & $6 \pm 0$ & $9,51 \pm 0,89$ & $9,91 \pm 0,54$ & $10,93 \pm 0,58$ & $13,59 \pm 0,94$ & $25,77 \pm 0,46$ \\
\hline
\end{tabular}

*Kontrol (-): CMC Na 1\%, kontrol (+): cefixime 30 bpj

Zona hambat yang terbentuk di sekitar $p a-$ per disc pada uji efektivitas disebabkan karena adanya difusi senyawa antimikroba dari ekstrak etanol daun Upo-upo yang terdistribusi pada medium yang terdapat bakteri. Ekstrak etanol daun Upo-upo memiliki efek sebagai antibakteri diduga karena kandungan senyawa alkaloid, flavonoid, tanin, dan terpenoid. Sebagaimana penelitian sebelumnya yang menunjukkan bahwa ekstrak etanol daun Phyllodium pulchellum (L.)
Desv. memiliki aktivitas antibakteri terhadap tiga bakteri Gram-positif (Bacillus subtilis, Staphylococcus aureus, Streptococcus pyogenes) dan tiga bakteri Gram-negatif (Pseudomonas aeruginosa, Klebsiella pneumonia, Escherichia coli) [20].

Mekanisme kerja alkaloid sebagai antibakteri adalah dengan cara mengganggu komponen penyusun peptidoglikan pada sel bakteri, sehingga lapisan dinding sel tidak terbentuk secara utuh dan menyebabkan kematian sel [22]. Aktifitas fla- 
vonoid sebagai antibakteri adalah melalui hambatan fungsi membran sel dengan membentuk senyawa kompleks dengan protein ekstraseluler dan terlarut sehingga dapat merusak membran sel bakteri dan diikuti dengan keluarnya senyawa intraseluler. Tanin diduga dapat mengkerutkan dinding sel sehingga mengganggu permeabilitas sel itu sendiri dan menyebabkan kerusakan dinding sel. Aktifitas terpenoid sebagai antibakteri diduga dengan melibatkan kerusakan membran sel oleh senyawa lipofilik. Terpenoid dapat bereaksi dengan porin (protein transmembran) pada membran luar dinding sel bakteri, membentuk ikatan polimer yang kuat, dan merusak porin, serta mengurangi permeabilitas dinding sel bakteri, akibatnya sel bakteri kekurangan nutrisi dan pertumbuhannya akan terhambat atau mati. Mekanisme kerja steroid sebagai antibakteri adalah dengan cara merusak membran sel bakteri [23].

\section{Kesimpulan}

Ekstrak etanol daun Upo-upo pada konsentrasi $1 ; 1,5 ; 2$; dan 2,5\% dapat menghambat pertumbuhan Streptococcus viridans dan Streptococcus pyogenes, dimana semakin tinggi konsentrasi ekstrak maka semakin besar pula zona hambat yang dihasilkan.

\section{Ucapan Terimakasih}

Ucapan terima kasih disampaikan kepada Kementerian Riset Teknologi/Badan Riset dan Inovasi Nasional atas hibah DRPM tahun 2020, Lembaga Penelitian dan Pengabdian Masyarakat (LPPM) Universitas Indonesia Timur, para reviewer internal Universitas Indonesia Timur, serta civitas akademika Farmasi Universitas Indonesia Timur.

\section{Daftar Pustaka}

1. Ljubin-sternak S, Marijan T, Jurekovic II, Bogovic
JC, Gagro A, Vranes J. Etiology and Clinical Characteristics of Single and Multiple Respiratory Virus Infection Diagnosed in Croatian Children in Two Respiratory Seasons. Journal of Pathogens. 2016.

2. Kemenkes RI, Riset Kesehatan Dasar; RISKESDAS, Jakarta: Balitbang Kemenkes RI; 2013.

3. Aprilianti S, Fusvita A, Setiawan A. Pemeriksaan Anti Streptolisin-O (ASTO) Sebagai Penanda Infeksi Streptococcus $\beta$ hemoliticus Di RSUD Kota Kendari dan RSUD Bahteramas. Jurnal Medika Udayana. 2019;8(12):1-5.

4. Zuhdi M, Triola AS, Teti VA. Hubungan Antara Usia Dengan Ukuran Tonsil Pada Tonsilitis Kronis Di Rumah Sakit Islam Siti Rahmah Padang Sumatera Barat Pada Tahun 2017 - 2018. Health and Medical Journal. 2020;2(1):19-28.

5. Dewi AAAS, Noviyani R, Niruri R, Suherman FS, Triyasa IP. Penentuan Streptococcus Group A Penyebab Faringitis Pada Anak Menggunakan McIsaac Score dan Rapid Antigen Detection Test (RADT) Dalam Upaya Penggunaan Antibiotika Secara Bijak. Jurnal Biologi. 2013;17(1):6-9.

6. Novialdi N, Pulungan MR. Mikrobiologi Tonsilitis Kronis. Fakultas Kedokteran Universitas Andalas; 2010.

7. Cappucino JG, Sherman N. Manual Laboratorium Mikrobiologi. Jakarta: Penerbit Buku Kedokteran EGC; 2014.

8. Mindarti F, Rahardjo PS, Kodrat L, Sulaiman BA. Hubungan Antara Kadar Anti Streptolisin-O dan Gejala klinis Pada Penderita Tonsilitis Kronis. Jurnal Kedokteran Yarsi. 2010;18(2):121-8.

9. Pratama LP, Purwanta M, Qurnianingsih E. Efektivitas Ekstrak Etanol Biji Kurma Mesir (Phoenix dactylifera. L.) Sebagai Antibakteri Terhadap Streptococcus pyogenes Secara In Vitro. Jurnal Kedokteran Syiah Kuala. 2019;19(3):13540.

10. Hendriani N, Suharti N, Julizar. Perbedaan Efek Daya Hambat Jus Kulit Buah Manggis dengan Air Rebusan Kulit Buah Manggis Sebagai Antibakteri Terhadap Bakteri Gram-Positif (Staphylococcus aureus dan Streptococcus pyogenes) Secara In Vitro. Jurnal Kesehatan Andalas. 2016;5(1):256- 
60.

11. Isnaeni D, Sjahril R, Massi MN. Perbandingan Bakteri Streptococcus pada Swab Tongsilofaringitis dengan Darah. Jurnal Pasca Universitas Hasanuddin. 2012.

12. Fan YC, Yue SJ, Guo ZL, Xin LT, Wang CY, Zhao DL, Guan HS, Wang CY. Phytochemical composition, hepatoprotective, and antioxidant activities of Phyllodium pulchellum (L.) Desv. Molecules. 2018;23(6):1361.

13. Rahman MK, Barua S, Islam MF, Islam MR, Sayeed MA, Parvin MS, Islam ME. Studies on the antidiarrheal properties of leaf extract of Desmodium pulchellum. Asian Pacific Journal of tropical Biomedicine. 2013;3(8):639-43.

14. Marjoni R. Dasar-Dasar Fitokimia Untuk Diploma III Farmasi. Jakarta: CV Trans Info Media; 2016.

15. Sirait AY, Pelealu NC, Yamlean PVY. Uji Daya Antibakteri Ekstrak Etanol Umbi Wortel (Daucus carota L.) Terhadap Staphylococcus aureus dan Escherichia coli Secara In Vitro. Pharmacon Jurnal Ilmiah Farmasi. 2016;5(4):145-54.

16. Djide MN, Sartini. Analisis Mikrobiologi Farmasi Cetakan kedua. Laboratorium Mikrobiologi Farmasi. Fakultas Farmasi Universitas Hasanuddin; 2008.

17. Milah N, Pengaruh Konsentrasi Antibakteri Propolis Terhadap Pertumbuhan Bakteri Streptococcus pyogenes Secara In Vitro (Doctoral
Dissertation, Universitas Negeri Semarang); 2017.

18. Bastian S, Rotinsulu H, Fatimawali. Uji Aktivitas Antimikroba dari Jamur Laut yang Berasosiasi dengan Spons Callyspongia sp. Pharmacon Jurnal Ilmiah Farmasi. 2018;7(3):311-20.

19. Harborne JB. Metode Fitokimia. Penuntun Cara Modern Menganalisis Tumbuhan. Terjemahan Padmawinata K dan Soediro I. Bandung: Penerbit ITB; 1987.

20. Velmurugan G, Anand SP. Preliminary Phytochemical Screening and Antibacterial Activity of Phyllodium pulchellum L. Desv. An Important Medical Plant. International Journal of Advanced Research. 2016;4(2):785-91.

21. Davis WW, Stout TR. Disc Plate Method of Microbiological Antibiotic Assay: II. Novel Procedure Offering Improved Accuracy. Applied microbiology. 1971;22(4):666-70.

22. Darsana IGO, Besung INK, Mahatmi H. Potensi Daun Binahong (Anredera cordifolia (Tenore) Steenis) dalam Menghambat Pertumbuhan Bakteri Escherichia coli Secara In Vitro. Jurnal Indonesia Medicus Veterinus. 2012;1(3):337-51.

23. Amalia A, Sari I, Nursanty R. Aktivitas Antibakteri Ekstrak Etil Asetat Daun Sembung (Blumea balsamifera (L.) DC.) Terhadap Pertumbuhan Bakteri Methicilin Resistant Staphylococcus aureus (MRSA). Prosiding Seminar Nasional Biotik. 2017;4(1):387-91. 